\title{
Pengelolaan Keuangan Badan Usaha Milik Desa (BUMDes) Berdasarkan Standar Akuntansi Keuangan - Entitas Tanpa Akuntabilitas Publik (SAK - ETAP)
}

\section{Victorson Taruh ${ }^{1}$, Usman $^{2}$}

1,2 Jurusan Akuntansi, Fakultas Ekonomi, Universitas Negeri Gorontalo, Jl. Jend. Sudirman

No. 6 Kota Gorontalo, Gorontalo 96128, Indonesia

E-mail: Victortaruh07846@gmail.com ${ }^{1}$, usmanpattiwi@gmail.com $^{2}$

\section{Article History: \\ Received: 01-11-2021 \\ Revised: 05-11-2021 \\ Accepted: 06-11-2021}

Keywords: Laporan Keuangan

BUMDes, SAK-ETAP

\begin{abstract}
:
Laporan keuangan yang dibuat oleh pengurus BUMDes Desa Botubarani belum mencerminkan model laporan keuangan berdasarkan SAK ETAP karena masih dalam bentuk laporan kas harian, yang menggambarkan kas masuk dan kas keluar. Tujuan pengabdian ini yaitu untuk mendesain laporan keuangan berdasarkan Standar Akuntansi Keuangan untuk Entitas tanpa Akuntabilitas Publik (SAK-ETAP). Pengabdian ini dilakukan kepada pengurus BUMDes di Desa Botubarani Kecamatan Kabila Bone Kabupaten Bone Bolango yang berhubungan langsung dengan pengelolaan keuangan. Metode pelatihan yang digunakan dalam pengabdian ini adalah memberikan materi dan praktek langsung kepada setiap pengurus BUMDes tentang pengelolaan keuangan BUMDes berdasarkan Standar Akuntansi Keuangan untuk Entitas Tanpa Akuntabilitas Publik (SAK-ETAP) dan untuk memberikan pemahaman secara mendalam tentang pengelolaan keuangan BUMDes secara relevan, andal, dapat dibandingkan dan dapat dipahami secara baik. Hasil yang diperoleh dalam pengabdian ini peserta dapat memahami mempraktekkan penyusunan model laporan keuangan berdasarkan Standar Akuntansi Keuangan untuk Entitas Tanpa Akuntabilitas Publik (SAK-ETAP).
\end{abstract}

\section{Pendahuluan}

Badan Usaha Milik Desa (BUMDes) merupakan suatu badan hukum yang didirikan oleh desa dan/atau bersama desa guna mengelola usaha, memanfaatkan aset, mengembangkan investasi dan produktivitas, menyediakan jasa pelayanan, dan/atau menyediakan jenis usaha lainnya untuk sebesar-besarnya kesejahteraan masyarakat Desa. BUMDes didirikan dengan tujuan sebagai motor pembangunan ekonomi tingkat desa. Pembangunan ekonomi pedesaan didasarkan oleh kebutuhan, potensi, kapasitas desa, dan modal yang dimiliki dari pemerintah desa dalam bentuk pembiayaan dan kekayaan desa yang bertujuan untuk meningkatkan kesejahteraan masyarakat desa. Adapun yang menjadi dasar pembentukan BUMDes sebagai penggerak pembangunan di desa lebih didasari pada prakarsa pemerintah dan masyarakat desa yang berdasarkan pada prinsip kooperatif, partisipatif, dan emansipatif dari masyarakat desa.

Undang-Undang No.6 Tahun 2014 dinyatakan bahwa Badan Usaha Milik Desa adalah badan usaha yang seluruh atau sebagian besar modalnya dimiliki oleh desa melalui penyertaan secara langsung yang berasal dari kekayaan desa yang dipisahkan guna mengelola aset, jasa 
pelayanan, dan usaha lainnya untuk sebesar-besarnya kesejahteraan masyarakat desa. BUMDes bertujuan mengoptimalkan pengelolaan aset-aset desa yang ada, memajukan perekonomian desa, serta meningkatkan kesejahteraan masyarakat desa. Dewi (2014) mengungkapkan bahawa BUMDes merupakan suatu penggerak perekonomian desa, sebagai lembaga usaha yang menghasilkan Pendapatan Asli Desa (PADes), serta sebagai sarana untuk mendorong percepatan peningkatan kesejahteraan masyarakat padesaan.

Pertanggungjawaban keuangan yang berkualitas tentunya sangat diharapkan oleh para pemangku kepentingan sebagaimana yang dijelaskan dalam Peraturan Pemerintah No. 71 Tahun 2010 Tentang Standar Akuntansi Pemerintahan dengan 4 kriteria normatif yang diperlukan yakni harus relevan, andal, dapat dibandingkan dan dapat dipahami. Laporan keuangan dikatakan relevan apabila dapat mempengaruhi keputusan ekonomi pemakai, yaitu dengan cara dapat beguna untuk mengevaluasi peristiwa masa lalu. demikian pula bahwa Laporan keuangan dapat dikatakan andal jika tidak memiliki atau bebas dari pengertian yang menyesatkan, kesalahan material, dan penyajiannya dengan tulus atau jujur dan Informasi yang berkualitas adalah informasi yang dapat dengan mudah dipahami oleh pembacanya. Informasi yang melatarbelakangi setiap butir informasi utama yang termuat dalam laporan keuangan diungkapkan dengan jelas agar kekeliruan dalam penggunaan informasi tersebut dapat dicegah.

Selanjutnya hal yang mendasar dalam penulisan karya pengabdian ini didukung oleh beberapa penelitian terdahulu diantaranya Susanto, et. al. (2020) dalam penelitiannya mengungkapkan bahwa ketatnya persaingan bisnis pada perusahaan saat ini menuntut perusahaan untuk dapat menyediakan informasi-informasi yang dapat digunakan sebagai dasar dalam pengambilan keputusan. Informasi dalam berbagai bentuk dibutuhkan makin cepat, lengkap, dan sesuai dengan standar, antara lain informasi untuk mengambil keputusan adalah laporan keuangan perusahaan. Laporan keuangan adalah catatan yang berisi informasiinformasi mengenai keuangan sebuah perusahaan yang diringkas dari transaksi-transaksi keuangan dalam suatu periode tertentu yang dapat digunakan untuk melihat atau menggambarkan kinerja perusahaan tersebut. Laporan keuangan bertujuan untuk menghasilkan informasi yang menyangkut posisi keuangan, kinerja serta perubahan posisi keuangan. Menurut Ikatan Akuntan Indonesia, tujuan laporan keuangan adalah menyediakan informasi posisi keuangan, kinerja keuangan, dan laporan arus kas suatu entitas yang bermanfaat bagi sejumlah besar pengguna dalam pengambilan keputusan ekonomi. Dalam penelitian Susanto dkk (2020) juga dijelaskan bahwa dalam laporan keuangan umumnya terdiri dari beberapa laporan yaitu: Balance Sheet, Income Statement, Perubahan Modal, Arus Kas dan Laporan Catatan Atas Laporan Keuangan. Melihat betapa pentingnya sebuah laporan keuangan dalam menilai kesehatan perusahaan, maka laporan keuangan harus disusun dengan kaidah-kaidah dan prinsip akuntansi yang berlaku umum, di Indonesia adalah Standar Akuntansi Keuangan (SAK).

Standar Akuntansi Keuangan (SAK) adalah suatu pedoman dalam penyusunan laporan keuangan agar terjadi keseragaman, ketepatan dapat diperbandingkan, dan dapat dimengerti, serta tidak menyesatkan dalam penyajian laporan keuangan. Hal lain penelitian yang dilakukan oleh Apriyanti dalam penelitian Susanto dkk (2020) menyatakan bahwa Standar Akuntansi Keuangan di Indonesia terdiri atas 5 pilar yaitu Pernyataan Standar Akuntansi KeuanganInternational Financial Report Standard (PSAK IFRS), Standar Akuntansi Keuangan untuk Entitas Tanpa Akuntansi Publik (SAK-ETAP), Standar Akuntansi Keuangan Syariah (SAK Syariah), Standar Akuntansi Pemerintah (SAP) dan Standar Akuntansi Keuangan Entitas Mikro, Kecil dan Menengah (SAK EMKM). PSAK IFRS diterapkan untuk entitas dengan akuntabilitas publik. Pada umumnya perusahaan menengah dan kecil sering menemukan kesulitan dalam menerapkan Pernyataan Standar Akuntansi Keuangan, sehingga pada tanggal 
17 Juli 2009 Ikatan Akuntan Indonesia (IAI) menerbitkan Standar Akuntansi Keuangan untuk Entitas Tanpa Akuntabilitas Publik (SAK ETAP) dan telah disahkan oleh DSAK IAI pada tanggal 19 Mei 2009. SAK ETAP digunakan untuk suatu badan yang tidak memiliki akuntabilitas publik signifikan (entitasnya belum terdaftar pada otoritas pasar modal atau regulator lain untuk tujuan penerbitan efek di pasar modal) dalam menyusun laporan keuangan untuk tujuan umum. SAK ETAP bertujuan untuk memudahkan pengusaha kecil atau menengah untuk menyusun laporan keuangan sehingga dapat berguna bagi pihak intern.

Berdasarkan beberapa permasalahan yang dihadapi oleh pengurus BUMDes tentang pengelolaan keuangan maka dibutuhkan pelatihan pembuatan laporan keuangan bagi pengelola BUMDes berdasarkan Standar Akuntansi Keuangan untuk Entitas Tanpa Akuntabilitas Publik (SAK ETAP) di Desa Botubarani Kabupaten Bone Bolango Provinsi Gorontalo yang juga merupakan desa binaan dari Universitas Negeri Gorontalo berdasarkan MOU yang telah disepakati dan ditandatangani oleh Universitas Negeri Gorontalo dan Pemerintah Daerah Botubarani Kabupaten Bone Bolango Provinsi Gorontalo. selain itu alasan melakukan pelatihan pengelolaan keuangan pada BUMDes berdasarkan SAK-ETAP di Desa Botubarani Kabupaten Bone Bolango Provinsi Gorontalo dikarenakan BUMDes merupakan salah satu tulang punggung pertumbuhan perekonomian desa guna mendongkrak pendapatan asli desa sehingga dengan hal tersebut pengelolaan manajemen BUMDes dapat dilaksanakan dengan baik. Pelatihan yang diberikan kepada pengurus BUMDes berupa keahlian, pengetahuan dan pengalaman untuk menyusun model laporan keuangan berdasarkan SAK ETAP pada BUMDes di Desa Botubarani sehingga dengan kegiatan pelatihan ini dapat menambah pengetahuan dan pengalaman bagi pengurus BUMDes melalui materi-materi yang diberikan oleh narasumber yang sudah cukup berpengalaman di bidang akuntansi. Dengan pemberian pelatihan diharapkan dapat memberikan pemahaman dalam mengelola keuangan BUMDes sehingga laporan keuangan yang disusun dapat menghasilkan data yang akurat dan akuntabel. Demikian pula dengan memberikan pelatihan kepada pengurus BUMDes melalui berbagai event maka pengelolaan keuangan BUMDes yang ada di Desa Botubarani dapat disusun secara andal, akurat, transparan dan akuntabel.

\section{Metode}

Tim pengabdian melakukan sosialisasi kepada pengelola keuangan BUMDes berdasarkan SAK ETAP dan merupakan langkah awal dalam proses pendekatan agar tujuan mudah tercapai. Dengan adanya sosialisasi tersebut akan terjalin hubungan baik yang dilandasi oleh kepentingan yang sama yaitu meningkatkan pemahaman dan kemampuan menyusun laporan keuangan BUMDes berdasarkan SAK ETAP. Tim melakukan koordinasi dengan Kepala Desa Botubarani Kabupaten Bone Bolango Provinsi Gorontalo untuk menanyakan apa pelatihan yang dibutuhkan bagi BUMDes tersebut. Salah satu hal yang dibutuhkan BUMDes adalah pengelolaan keuangan BUMDes berdasarkan stadar yang berlaku umum yaitu SAK ETAP. Program pelatihan pengelolaan keuangan BUMDes dilaksanakan di Desa Botubarani sesuai kesepakatan pemerintah Desa. Pelaksanaan kegiatan pengabdian ini dilakukan dengan beberapa metode, yaitu:

1. Ceramah

Metode ini memberikan penjelasan kepada para peserta tentang peraturan dan standar dalam pengelolaan keuangan BUMDes berdasarkan SAK ETAP. Selain itu, peserta juga dikenalkan berbagai macam bentuk laporan keuangan dan mengenal pentingnya menyusun laporan keuangan BUMDes sebagai bentuk akuntabilitas kepada masyarakat desa. Metode 
ceramah ini dilakukan selama 2 jam. Media yang digunakan untuk membantu kelancaran presentasi yaitu laptop dan LCD Proyektor.

\section{Tutorial}

Peserta pelatihan diberikan materi tentang tahapan penyiapan dokumen untuk mempersiapkan penyusunan laporan keuangan. Selain itu, peserta juga diberikan contoh kasus serta tahapan dalam menyusun laporan keuangan berdasarkan SAK ETAP. Tahap kedua ini dilakukaan selama 3 jam. Media yang mendukung dalam mempraktikan penyusunan laporan keuangan yaitu Ms. Excel dan aplikasi Accurate Accounting Versi V.

\section{Diskusi}

Peserta diberikan kesempatan untuk mendiskusikan permasalahan yang berkaitan dengan penyusunan laporan keuangan dan kesulitan yang mereka alami. Tahap ketiga ini dilakukan selama 1 jam. Media yang mendukung saat diskusi yaitu Laptop, LCD Proyektor, Whiteboard dan Spidol.

\section{Pendampingan}

Langkah ini merupakan hal yang paling penting karena peserta didampingi dalam penyusunan laporan keuangan desa sampai mereka paham. Tahap keempat dilakukan selama 3 jam. Media yang sangat penting saat melaksanakan pendapingan yaitu kertas berisi contohcontoh penyusunan laporan keuangan desa.

\section{Evaluasi}

Evaluasi pada awal kegiatan dilakukan dalam tiga tahap yakni; Mulai dari perencanaan, Proses pelaksanaan dan Evaluasi seperti gambar berikut:

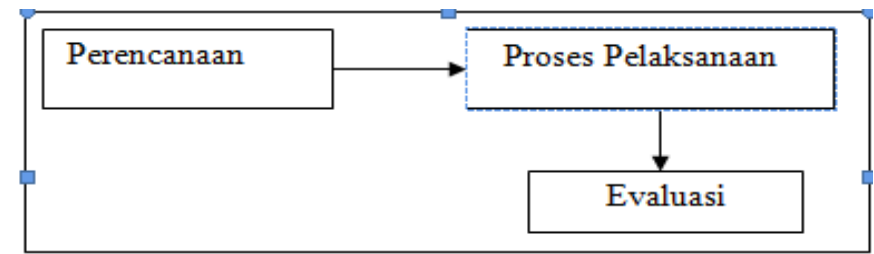

Gambar 1. Evaluasi Kegiatan

Evaluasi pada awal kegiatan dilakukan untuk menetapkan rencana kegiatan yang akan dilakukan evaluasi. Proses pelaksanaan dilakukan untuk mengetahui keterlaksanaan program. Sementara evaluasi pada akhir kegiatan dilakukan untuk mengukur tingkat keberhasilan dari keseluruhan program kegiatan dengan tema pelatihan pengelolaan keuangan Badan Usaha Milik Desa (BUMdes) berdasarkan SAK-ETAP di Desa Botubarani Kabupaten Bone Bolango Provinsi Gorontalo.

\section{Hasil}

Kegiatan pengabdian ini memfokuskan pada pengelolaan keuangan Badan Usaha Milik Desa (BUMDes) berdasarkan SAK-ETAP di Desa Botubarani Kabupaten Bone Bolango Provinsi Gorontalo dilakukan secara tatap muka dengan tetap memperhatikan protokol kesehatan dari pemerintah pada masyarakat yang tergabung pada Badan Usaha Milik Desa (BUMDes) di Desa Botubarani Kecamatan Kabila Bone Kabupaten Bone Bolango. Rata- 
rata jenis usaha yang dikelola oleh Badan Usaha Milik Desa (BUMDes) di Desa Botubarani Kecamatan Kabila Bone Kabupaten Bone Bolango adalah pengolahan ikan seperti, sambal sagela, abon ikan dan bakso ikan, selain itu usaha jasa juga turut diminati oleh masyarakat Desa Botubarani Kecamatan Kabila Bone Kabupaten Bone Bolango seperti penyewaan pondok/gazebo, alat pancing, alat renang, perahu dan usaha penyewaan ban dalam dll.

\section{a. Peserta Pelatihan}

Pelatihan ini diikuti sekitar 30 orang peserta dari pengelola badan usaha milik desa (BUMDes) dan aparat desa maupun masyarakat sekitar pantai di Desa Botubarani Kecamatan Kabila Bone Kabupaten Bone Bolango. Pelatihan dan sosialisasi tersebut dilakukan agar pengelola Badan Usaha Milik Desa (BUMDes) yang ada di Desa Botubarani Kecamatan Kabila Bone Kabupaten Bone Bolango dapat dikelola dengan baik terutama dalam Pengelolaan Keuangan Badan Usaha Milik Desa (BUMDes) berdasarkan SAK ETAP di Desa Botubarani Kabupaten Bone Bolango Provinsi Gorontalo untuk meningkatkan transparansi dan akuntabilitas keuangan pada Badan Usaha Milik Desa (BUMDes).

Pengelolaan keuangan berdasarkan SAK ETAP tersebut memiliki manfaat sebagai media transparansi, media akuntabilitas publik, sarana informasi, serta sarana evaluasi kinerja. Sebagai media transparansi yang berguna untuk memberikan informasi keuangan yang terbuka dan jujur kepada publik berdasarkan pertimbangan bahwa publik memiliki hak untuk mengetahui secara terbuka dan menyeluruh atas pertanggungjawaban pemerintah dalam pengelolaan sumber daya yang dipercayakan maupun ketaatan terhadap peraturan perundangundangan

\section{b. Capaian Hasil Pelaksanaan}

Pelatihan tersebut dilakukan secara langsung di Aula Kantor Desa botubarani tentang Pengelolaan Keuangan Badan Usaha Milik Desa (BUMDes) berdasarkan SAK ETAP di Desa Botubarani Kabupaten Bone Bolango Provinsi Gorontalo untuk meningkatkan transparansi dan akantabilitas pengelolaan keuangan pada Badan Usaha Milik Desa (BUMDes). dengan adanya pelatihan tersebut pengelolaan keuangan Badan Usaha Milik Desa (BUMDes) berdasarkan SAK ETAP di Desa Botubarani Kabupaten Bone Bolango Provinsi Gorontalo maka peserta lebih memahami penjelasan dan petunjuk- petunjuk riil lapangan yang disampaikan oleh narasumber atau pemateri dalam meningkatkan keterampilan untuk mengelola keuangan pada Badan Usaha Milik Desa (BUMDes) di Desa Botubarani Kabupaten Bone Bolango Provinsi Gorontalo kearah yang lebih baik dan lebih professional. Dengan adanya bentuk pelatihan tersebut tentang pengelolaan keuangan Badan Usaha Milik Desa (BUMDes) berdasarkan SAK ETAP di Desa Botubarani Kabupaten Bone Bolango Provinsi Gorontalo dapat terbantu dalam mengelola keuangan BUMDes sehingga pengelolaan keuangan tersebut dapat lebih transparan dalam menjalakan usahanya.

Dalam pelatihan ini pemateri menjelaskan standar yang berlaku dalam menyusun laporan keuangan BUMDes. Pada sesi ini peserta dijelaskan standar akuntansi keuangan berdasarkan SAK ETAP. Sesi kedua, peserta diberikan penjelasan cara mencatat jurnal ketika ada transaksi. dan sesi ketiga peserta juga diberikan contoh kasus dan cara membuat jurnalnya serta memposting kedalam buku besar. Sesi empat, pada sesi ini diisi dengan tanya jawab antara tim pengabdian dengan para pengelola keuangan BUMDes. Para peserta diberikan waktu 30 menit untuk berdiskusi serta menyampaikan kesulitan yang dialami. Sesi lima, mempraktikan membuat laporan keuangan BUMDes sesuai dengan standar yang berlaku. Peserta membuat laporan keuangan desa dan tim pengabdi memantau serta membantu jika ada kesulitan yang dialami peserta. 
Hal yang menjadi catatan adalah pentingnya kerjasama antara institusi dengan desa binaan, karena untuk jangka panjangnya tidak hanya pelatihan saja tetapi pendampingan secara berkelanjutan. Keberhasilan program pelatihan ini diukur dengan parameter: 1. Melakukan input data transaksi hingga mampu menyusun laporan keuangan 2. Meningkatnya kualitas informasi bagi masyarakat sebagai dasar evaluasi kinerja pengelolaan keuangan BUMDes di Desa Botubarani Kab. Bone Bolango Provinsi Gorontalo

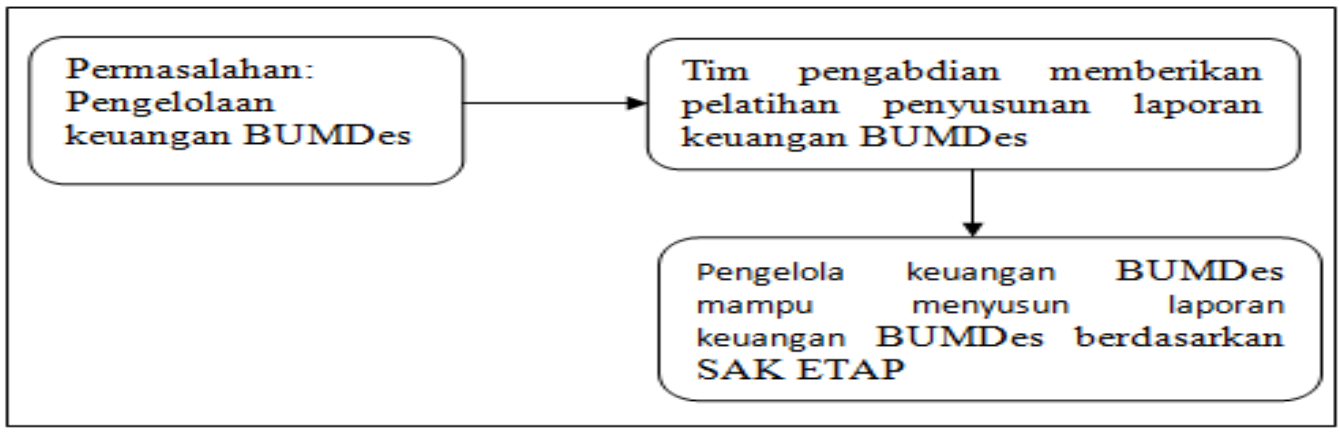

Gambar 2. Keberhasilan Pelaksanaan Pelatihan

\section{Diskusi}

Pelatihan tentang pengelolaan keuangan Badan Usaha Milik Desa (BUMDes) berdasarkan SAK ETAP di Desa Botubarani Kabupaten Bone Bolango Provinsi Gorontalo adalah untuk meningkatkan transparansi dan akuntabilitas keuangan BUMDes yang lebih baik. Dalam kegiatan pengabdian ini diharapkan pengelolaan keuangan BUMDes dapat dikelola berdasarkan standar yang berlaku secara umum yakni SAK ETAP agar keuangan BUMDes menjadi lebih tertib dan transparan. Dengan pengelolan keuangan yang baik dan transparan maka usaha yang dilakukan akan mudah mendapatkan bantuan dana baik dari pemerintah pusat dan daerah maupun dari lembaga-lembaga keuangan lainnya.

Kegiatan pengabdian ini tentang pengelolaan keuangan Badan Usaha Milik Desa (BUMDes) berdasarkan SAK ETAP di Desa Botubarani Kabupaten Bone Bolango Provinsi Gorontalo maka disarankan kepada seluruh pengelola atau pengurus BUMDes Botubarani Kecamatan Kabila Bone Kabupaten Bone Bolango dapat menambah pengetahuan dengan mengikuti seminar-seminar, pelatihan-palatihan yang dilaksanakan oleh beberapa instansiintasi pemerintahan maupaun dari lembaga-lembaga perguruan tinggi yang dilaksanakan setiap tahun agar dapat lebih trampil sehingga pengelolaan keuangan BUMDes dapat lebih baik, berkualitas, transparansi dan dapat dipertanggungjawabkan.

\section{Kesimpulan}

BUMDes merupakan suatu institusi ekonomi rakyat lembaga komersial, pertama-tama berpihak kepada pemenuhan kebutuhan (produktif maupun konsumtif) masyarakat melalui pelayanan distribusi penyediaan barang dan jasa. Dalam hal ini, BUMDes sebagai institusi komersial harus tetap memperhatikan efisiensi dan efektifitas dalam berbagai kegiatan sektor riil dan lembaga keuangan.

Pelatihan tentang pengelolaan keuangan Badan Usaha Milik Desa (BUMDes) berdasarkan SAK ETAP di Desa Botubarani Kabupaten Bone Bolango Provinsi Gorontalo yang dilaksanakan secara langsung dalam bentuk tatap muka di Aula Desa Botubarani 
Kecamatan Kabila Bone Kabupaten Bone Bolango dan peserta sangat antusias mengikuti pelatihan tersebut sampai akhir petemuan karena hal ini dipandang sangat penting dan urgen dalam pengelolaan keuangan sesuai standar pengelolaan keuangan yang berlaku secara umum. Dengan pengabdian ini pula peserta dapat memahami penjelasan pemateri dari materi yang disampaikan ataunara sumber dalam meningkatkan pengelolaan keuangan yang dikelolah dengan tertib, transparan dan dapat dipertanggunjawabkan. Dengan adanya bentuk pelatihan pengelolaan keuangan Badan Usaha Milik Desa (BUMDes) berdasarkan SAK ETAP di Desa Botubarani Kabupaten Bone Bolango Provinsi Gorontalo maka pengelola keuangan BUMDes mendapatkan bekal ilmu dalam pengelolaan keuangan yang lebih berkualitas, transparan dan dapat dipertanggungjawabkan kearah yang lebih baik.

\section{Pengakuan/Acknowledgements}

Terima kasih kepada seluruh pihak yang telah memberikan kontribusi baik secara langsung maupun tidak langsung sehingga kegiatan pengabdian ini dapat terlaksana dengan baik. Terima kasih kepada Kepala Desa Botubarani yang telah memberikan kesempatan bagi pengabdi untuk melaksanakan kegiatan pengabdian ini, dan teristimewa kepada pengelola BUMDes yang telah bersedia menjadi peserta pengabdian. Semoga apa yang telah disampaikan dalam kegiatan pengabdian ini dapat memberikan manfaat bagi BUMDes dalam menjalankan roda organisasi yang lebih baik.

\section{Daftar Referensi}

Afrijal, \& Ramadhani. (2016). Analisis Perbandingan Kinerja Keuangan Badan Usaha Milik Desa (BUMDES) Di Kabupaten Rokan Hulu. Jurnal Ilmiah Cano Ekonomos, 5(1), 110.

Arianti, Fitrie, E. Y. A., \& Darwanto, E. W. K. (2016). Pengembangan Desa Mandiri Melalui Pengelolaan Badan Usaha Milik Desa (BUMDes). Jurnal Dinamika Ekonomi \& Bisnis, 13(1).

Ikatan Akuntan Indonesia (IAI). (2015). Standar Akuntansi Keuangan ETAP. Ikatan Akuntan Indonesia.

Kementerian Keuangan RI, Laporan keuangan yang harus dibuat oleh pengelola BUMDes yaitu laporan laba rugi, laporan perubahan equitas, neraca, laporan arus kas, dan catatan atas laporan keuangan. Retrieved from https://klc.kemenkeu.go.id/pusknpk-laporankeuangan-bumdes

Laporan Keuangan Pemerintah Sebagai Wujud Akuntabilitas Pengelolaan Keuangan Negara. https://djpb.kemenkeu.go.id. Diakses pada tanggal 3/06/2021

Nurniah, Sukriah, \& Istiyana. (2019). IBM Pelatihan Dan Pendampingan Penyusunan Laporan Keuangan Pada BUMDes Assamaturu. Jurnal Prosiding Seminar Nasional Penelitian \& Pengabdian Kepada Masyarakat, 6(3), 389-394.

Pratiwi, A. ., Sondakh, J. ., \& Kalangi, L. (2014). Analisis Penerapan SAK ETAP pada Penyajian Laporan Keuangan PT Nichindo Manado Suisan. Jurnal EMBA, 2(3), 254265.

Pratiwi, D. N., \& Muliasari, D. (2020). Pendampingan Pengelolaan Keuangan Desa Guna 
Meningkatkan Akuntabilitas di Desa Mlandi Wonosobo. Jurnal Ilmiah Pengabdhi, 6(2), 158-162. http://journal.trunojoyo.ac.id/pangabdhi ISSN: 2477-6289.

Ramadana, Berlian, C., Ribawanto, H., \& Suwondo. (2013). Keberadaan Badan Usaha Milik Desa (BUMDES) Sebagai Penguatan Ekonomi Desa (Studi di Desa Landungsari, Kecamatan Dau, Kabupaten Malang. Jurnal Administrasi Publik, 1(6), 1068-1076.

Suleman, A. R., Revida, E., Soetijono, I. K., Siregar, R. T., Syofyan, \& Hasibuan, A. F. H. (2020). BUMDes Menuju Optimalisasi Ekonomi Desa. Yayasan Kita Menulis. 